\title{
Research on Corporate Social Responsibility and Harmonious Labor Relations
}

\author{
Jianju Wang, Jingzhe Zhang* \\ School of Business Administration, Human Resource Management \\ Guizhou University of Finance and Economics \\ Guiyang, China \\ 280510329@qq.com
}

\begin{abstract}
The report of the 19th National Congress pointed out that improving the consultation and coordination mechanism involving the government, trade unions and enterprises to build a harmonious labor relationship is the basis for safeguarding and improving people's livelihood and promoting social harmony. The deepening of economic globalization has led to the gradual exposure of corporate social responsibility issues, such as the arrears of wages and neglect of work safety, labor disputes and labor disputes are on the rise, and corporate social responsibility awareness is gradually weakening. Stable labor relations can promote the healthy development of enterprises, and building harmonious labor relations is the social responsibility that enterprises should undertake. Based on this, this paper analyzes the importance of corporate social responsibility through literature review methods, and finds out the problems of corporate social responsibility in labor relations and the path choice of building harmonious labor relations.
\end{abstract}

Keywords-Harmonious labor relationship; Corporate social responsibility; Path selection

\section{INTRODUCTION}

Since the 18th National Congress of the Communist Party of China, "developing harmonious labor relations" has become an important part of building a harmonious society. Emphasizing the construction of harmonious labor relations is the premise of building a harmonious society and plays an important role in the harmony and stability of the whole society. Since China is now in the deep water area of reform, the mechanism for adjusting labor relations at this stage is not perfect. More and more enterprises are gradually weakening their sense of social responsibility from the perspective of pursuing profit maximization, arrears wages and neglect of workers. Security, labor disputes and other similar phenomena occur from time to time. These wide-ranging social problems have seriously jeopardized the harmonious and stable development of society. The reasons for this are directly related to the incorrect implementation of social responsibility by business operators. It can be seen from previous research that the degree of corporate social responsibility has a major impact on the harmony of labor relations, social stability, and the level of labor and social security.

Based on this, this paper analyzes the problems of labor relations in the process of fulfilling social responsibility while emphasizing corporate social responsibility. Therefore, enterprises are required to improve their social responsibilities, focus on cultivating the concept of corporate social responsibility, and build a harmonious labor relationship.

\section{BUILDING A HARMONIOUS LABOR RELATIONSHIP IS THE SOCIAL RESPONSIBILITY OF THE ENTERPRISE}

\section{A. The Basic Content of Corporate Social Responsibility}

Corporate social responsibility means that in the process of creating profits and value, the company must not only bear corresponding legal responsibilities to shareholders, but also bear corresponding responsibilities to other stakeholders of the enterprise. Among them, the stakeholders of the company include customers, employees, competitors, suppliers, governments and other social interest groups. Enterprises are the cells that make up society, and employees are the cells that make up the enterprise. At present, the field is based on the theory of corporate social responsibility of stakeholders. The social responsibility of enterprises to employees is the most basic social responsibility that enterprises should undertake. Employees directly participate in the production of enterprise products, and how the relationship between enterprises and employees directly affects the survival and development of enterprises. Therefore, enterprises should take into account the income of employees, protect the rights and interests of workers, focus on improving the labor relationship between enterprises and employees, and advocate the construction of harmonious labor relations.

\section{B. The Significance of Strengthening Social Responsibility to Build a Harmonious Labor Relationship}

Under the background of economic globalization, the moral constraints of enterprises on their own economic behaviors reflect the essential requirements of corporate social responsibility. This kind of moral constraint can not only better reflect the company's purpose and business philosophy, but also provide a kind of restraint behavior for the internal production and management behavior, which in turn affects management. Enterprises must not only assume corresponding social responsibilities, but also provide better solutions to relevant labor problems, focusing on building harmonious labor relations. [1] Only by strengthening the awareness of corporate social responsibility can we implement the "peopleoriented" scientific development concept and the concept of governing the country, and promote the material, political and spiritual civilization of China, in order to ensure that the citizens feel the warmth of the socialist family. 


\section{Basic Content of Labor Relations}

Labor relationship is a kind of social relationship, a relationship between laborers and employers in the use of labor ability and the realization of labor. This kind of social relationship is formed when people are engaged in labor. As the most basic social relationship and production relationship, it embodies the level of productivity development and is also a symbol of social progress. It forms social relations with other relationships. The grasp of the nature and characteristics of labor relations from different angles can refer to labor relations as employment relations, labor relations, and so on.

There is a certain labor relationship between the company and its employees. Therefore, correctly handling the labor relationship between enterprises and employees plays an important role in the sustainable development of enterprises.

\section{THE STATUS AND PROBLEMS OF ENTERPRISES FULFILLING THEIR SOCIAL RESPONSIBILITIES IN LABOR RELATIONS}

In recent years, the issue of corporate social responsibility has attracted great attention. It is hoped that enterprises should pay more attention to the interests of relevant stakeholders while contributing to the sustainable development of society and the environment while creating wealth. At present, the problems existing in the implementation of social responsibility of enterprises are mainly as follows:

\section{A. Labor Contract}

In the process of signing labor contracts with laborers, the expressions of labor contracts such as occupational hazards and social insurance are not complete, even in some industries, such as the need for labor quality is not particularly high, the workers themselves The awareness of rights protection is not high, and some enterprises will not sign relevant labor contracts with workers for their own interests. There are still some enterprises that have signed labor contracts with laborers and cannot follow the principle of equal negotiation. They cannot implement the corresponding obligations in accordance with the terms of the contract, and even arbitrarily terminate labor contracts and evade compensation for workers. The physical and mental damage caused by the workers causes some labor problems. [2]

\section{B. The Enterprise Negotiation Mechanism Is Not in Place}

In order to reduce expenses and reduce unnecessary waste of human resources, enterprises have not fully established a collective wage negotiation system and a reasonable salary scale and compensation system. It is not possible to communicate the specific system of the company to employees through effective channels, such as the implementation of the minimum wage standard is not in place, and the arrears of wages to employees have occurred. Tripartite coordination mechanisms for labor relations have not yet been established within some enterprises. If there is a labor conflict or labor dispute between the enterprise and the laborer, the enterprise trade union has a low status in the collective bargaining, and the chairman of the trade union has not really become the spokesperson of the employee, then the problem between the enterprise and the employee cannot be better.

\section{One-sided Pursuit of "Maximizing Economic Benefits"}

In a fiercely competitive environment, some companies aim to maximize economic profits. In order to ensure that enterprises can carry out production safely, and sometimes do not comply with relevant laws and regulations, employees of the company are organized to produce in the state of environmental protection, energy conservation, and labor protection. Some companies are responsible for inspections, although companies can provide the corresponding facilities, but they will only be put into use when the relevant departments check. In order to avoid taking corresponding responsibility, some wastes are still secretly discharged, which has a serious impact on the environment.

\section{Deceive and Defraud the Government's Support}

With the emergence of the global economy, the sharing economy is constantly coming to our side in response to this trend. Governments at all levels have successively issued policies to encourage enterprises to expand, expand and upgrade their technological transformation. Encourage enterprises to fully participate, strengthen investment promotion, and comprehensively expand regional economic development. Some of these companies use small investments to defraud project funds and tax incentives.

\section{STRENGTHEN CORPORATE SOCIAL RESPONSIBILITY AND BUILD A PATH OF HARMONIOUS LABOR RELATIONS}

The strengthening of corporate social responsibility requires coordination and cooperation between the government and enterprises to jointly promote the development of corporate social responsibility movement.

\section{A. Government Level}

Improve relevant laws and regulations, and strengthen law enforcement and supervision

Improve the current labor law and make it more applicable. Secondly, the corresponding legal system should be used together, distinguishing the primary and secondary, and giving full play to its role to improve the labor market. Finally, the current labor laws should be in line with the international standards, adapt to the gradual internationalization of labor relations in China, and achieve the unification of domestic labor relations adjustments and international labor standards practices.

After establishing and perfecting relevant labor laws, we will focus on strengthening the enforcement of labor law enforcement and supervision systems. The government should give relevant labor laws to publicize and widely publicize so that the broad masses of workers can truly understand their own interests and force enterprises to strictly follow the system stipulated by the law. Secondly, when monitoring the status of labor relations in enterprises, if the company is found to have infringement on the interests of employees, it should be strictly punished .[3] 
1) Encourage enterprises to actively assume social responsibility: The government should set a good example for the enterprise, actively play its role, and guide the enterprise to assume the corresponding responsibility to form the development strategy of the enterprise. First of all, from the perspective of ideology, let enterprises establish a sense of social responsibility. Secondly, starting from the institutional aspect, taking social responsibility as the norm of the enterprise, it is more beneficial and supervising the behavior of the enterprise. Indirectly clarify that enterprises must assume social responsibility. Finally, enterprises should establish corresponding evaluation index systems. When considering relevant indicators, not only economic indicators but also employment rates and employee satisfaction should be considered. From these indicators, companies are also developing towards harmonious labor relations.

\section{B. Social Level}

1) Actively publicize corporate social responsibility and strengthen public opinion supervision: Corporate social responsibility is not only conducive to the healthy development of the company itself, but also conducive to the formation of employees' social awareness. Strengthening social responsibility is an important part of building a harmonious labor relationship. Therefore, when emphasizing harmonious labor relations, it is more important to promote corporate social responsibility. Vigorously promote social responsibility, such as reporting to the society about the social responsibility of enterprises. For enterprises that violate laws and regulations, illegal employment, and violations of the legitimate rights and interests of workers, the news media should be brave enough to expose these companies to abide by the law and assume corporate social responsibility. Secondly, to promote the role of public opinion supervision to relevant employees, encourage more employees to participate, especially pay attention to the role of network supervision. Finally, emphasize that employees must understand rights. When their labor rights are violated, they must use legal channels to defend their rights.

2) Improve the participation of multi-interest groups in the coordination mechanism: The implementation of corporate social responsibility, the interest groups involved in this process are more complex, mainly trade unions, environmental protection interest groups, etc. At this stage, mainly through the relevant system design to increase the participation of interest groups. First of all, communication should be strengthened. In the process of formulating corporate social responsibility policies, relevant interest groups are encouraged to participate through seminars and information disclosure systems. Secondly, actively cultivating relevant interest groups is a necessary condition for interest groups to participate in negotiations. Some interest groups have the willingness to participate, but it is difficult to participate effectively due to the degree of their own development. In terms of policies, it is necessary to remove the obstacles that restrict the development of relevant interest groups, and adopt policies that are conducive to the development of relevant interest groups. This will effectively promote the participation of interest groups in the negotiation and regulation, and help to build a harmonious labor relationship in the perspective of social responsibility. [4]

\section{Enterprise level}

1) Establish a "people-oriented" concept and enhance corporate social responsibility: Enterprises must implement the people-oriented concept within the enterprise, and improve the labor and employment rules and regulations that are dominated by formal employment and informal employment, in order to express respect for the labor results of employees. First, popularize the legal and moral quality education for citizens. Secondly, enterprise managers must establish the idea of "harmony and benefit" and, through continuous efforts, gradually meet the needs of employees to promote cooperation between the two sides. The current work of the company focuses on gradually improving the working environment and comprehensively implementing the occupational safety and health system to protect the safety and health of workers; ensuring the right of employees to rest and vacation, so as to effectively ensure the reproduction of labor; and establish a reasonable corporate profit. The distribution mechanism respects and realizes the legal rights of employees in obtaining remuneration for labor. [5]

2) Transforming the business philosophy of the company and establishing the development concept of "citizen" enterprises: When a company exists in society as a "social person", it is not just a legal person, but a social citizen with civic awareness. In other words, society is the real environment for the survival and development of enterprises. Then the development of enterprises must be based on the acceptability of society, which is what we usually call "I am for everyone, everyone is for me." Only corporate citizens with such a concept can exist in a "harmonious society" in the long run, achieve harmonious development of economic goals and social goals, and achieve win-win for enterprises, employees and society.

\section{CONCLUSION}

In short, whether companies value social responsibility and how they fulfill their social responsibility status can directly affect the harmony between the company and its employees, and even affect the construction of a harmonious society. In the face of this situation, we should clarify the problems we are facing now, strengthen the awareness of corporate social responsibility, and build a harmonious labor relationship for the sustainable development of enterprises.

\section{REFERENCES}

[1] B.H. Dong and G. Li, "The New Position of Constructing Harmonious Labor Relations," Journal of Nanjing Normal University, vol. (02), pp. $67-76,2006$.

[2] J.H. Sun, K.Y. Tang, and Z.R. Wan, "Thoughts on Establishing Enterprise Credit System to Promote the Development of Harmonious 
Labor Relations_-Based onthe Perspective of Labor Security Supervision," China Labor, vol. 06, pp. 54-59, 2018.

[3] J. Fan, "Thoughts on Building a Harmonious Labor Relations Enterprise under the New Situation," Low Carbon World, vol. (36), pp. 170-171, 2016.
[4] Y.N. Niu, "The Basic Path of Promoting the Implementation of Corporate Social Responsibility by Chinese Trade Unions," Journal of Beijing Trade Union Cadre College ,vol. 35(03), pp. 14-17, 2015.

[5] C.P. Wu, "Labor Relationship Management of Small and Medium Private Enterprises Basedon the Perspective of Corporate Social Responsibility," Shopping Modernization, vol. (12), pp. 135-136, 2015. 